\title{
Surgical site infection among patients undergoing cardiac transplantation
}

\author{
JASN Rodrigues, REL Ferretti-Rebustini, RNT Turrini, RA Lacerda*, V de Brito Poveda \\ From 3rd International Conference on Prevention and Infection Control (ICPIC 2015) \\ Geneva, Switzerland. 16-19 June 2015
}

\section{Introduction}

The patient undergoing transplantation is susceptible to many diseases, especially the surgical site infections, which are the third leading cause of infection related to health care in Brazil.

\section{Objectives}

To analyze the occurrence and the predisposing factors for surgical site infection in patients undergoing cardiac transplantation, verifying the relationship between infections and variables related to the patient and the surgical procedure.

\section{Methods}

This retrospective cohort study was conducted exploring the medical records of patients older than 18 years who underwent heart transplantation. The correlation between variables was performed using the exact test of Fischer and Mann-Whitney-Wilcoxon.

\section{Results}

The sample consisted of 86 patients, predominantly men, with severe systemic disease, underwent extensive preoperative hospitalization. Showed signs of surgical site infection $9.3 \%$ of transplant, five $(62.5 \%)$ superficial incisional, two (25\%) and deep (12.5\%) of organ/space. There was no statistically significant association between variables related to the patient and the surgical procedure.

\section{Conclusion}

There was no association between variables and cases of surgical site infection, possibly related to the small number of cases of infection in the sample investigated.

Medical-Surgical, Nursing School of University of São Paulo, São Paulo, Brazil

\section{Disclosure of interest}

None declared.

Published: 16 June 2015

\section{doi:10.1186/2047-2994-4-S1-P75}

Cite this article as: Rodrigues et al:: Surgical site infection among patients undergoing cardiac transplantation. Antimicrobial Resistance and Infection Control 2015 4(Suppl 1):P75.
Submit your next manuscript to BioMed Central and take full advantage of:

- Convenient online submission

- Thorough peer review

- No space constraints or color figure charges

- Immediate publication on acceptance

- Inclusion in PubMed, CAS, Scopus and Google Scholar

- Research which is freely available for redistribution

Submit your manuscript at www.biomedcentral.com/submit
() Biomed Central

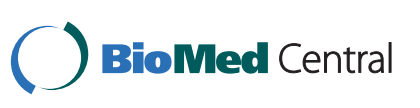

